\title{
Prevalence of Rotavirus in shellfish from Southern Kerala
}

\author{
Vysakh Mohan ${ }^{1}$, Shriya Rawat ${ }^{2}$, K. M. Lokesh ${ }^{3}$, H. V. Mohan ${ }^{4}$, D. Avinash Reddy ${ }^{1}$, Ashok Kumar ${ }^{1}$ and K. N. Bhilegaonkar ${ }^{1}$ \\ 1. Division of Veterinary Public Health, Indian Veterinary Research Institute, Bareilly, Uttar Pradesh, India; 2. Department \\ of Veterinary Public Health, Sardar Vallabhai Patel College of Veterinary and Animal Sciences, Meerut, Uttar Pradesh, \\ India; 3. Division of Veterinary Public Health, Guru Angad Dev Veterinary and Animal Sciences University, Ludhiana, \\ Punjab, India; 4. Department of Veterinary Public Health, Veterinary College, Bidar, Karnataka, India. \\ Corresponding author: Vysakh Mohan, e-mail: vysakhmohanvet@gmail.com, SR: shriyarawat@gmail.com, \\ KML: lokeshvph@gmail.com, HVM: mohanhv@gmail.com, AR: avi.incredible@gmail.com, AK: ashokakt@rediffmail.com, \\ KNB: kiranvph@rediffmail.com \\ Received: 21-06-2014, Revised: 26-08-2014, Accepted: 02-09-2014, Published online: 15-10-2014
}

doi: 10.14202/vetworld.2014.821-824. How to cite this article: Mohan V, Rawat S, Lokesh KM, Mohan HV, Avinash Reddy D, Kumar A, Bhilegaonkar KN. Prevalence of Rotavirus in shellfish from Southern Kerala. Veterinary World 7(10): 821-824.

\begin{abstract}
Aim: To study the prevalence of Rotavirus in shellfish from Southern Kerala.

Materials and Methods: The shellfish samples after processing was concentrated using proteinase K. RNA was isolated from the concentrated samples using phenol chloroform method. Rota viral RNA was detected using reverse transcriptionpolymerase chain reaction.
\end{abstract}

Results: A low prevalence of 2.5\% (5/200) was obtained during the study. Rotavirus was detected in 2 out of 60 brown mussels (3.33\%), 2 out of 70 yellow clams (2.86\%) and 1 out of 70 black clams (1.43\%).

Conclusion: Low prevalence of Rotavirus was obtained in our study. A more extensive study need to be conducted to estimate the prevalence of enteric virus in shellfish.

Keywords: concentration, proteinase K, reverse transcription-polymerase chain reaction, Rotavirus, shellfish.

\section{I ntroduction}

Globally, diarrhoeal diseases account for about one in six deaths among children younger than 5 years of age [1]. In India 2.3 million annual deaths are reported among children of which 334,000 are attributable to diarrhoeal diseases [1-3]. In developed and developing world, Rotavirus constitutes the foremost cause of severe diarrhea in children [3]. Rotavirus infection is responsible for 90,000-153,000 child deaths in India each year [4].

More than 140 viruses are present in human faeces [5] which can contaminate water bodies including shellfish growing areas. These enteric viruses cause a wide spectrum of illnesses in man including hepatitis, gastroenteritis, meningitis, fever, rash, conjunctivitis, and may be diabetes or severe acute respiratory syndrome. Shellfish which are important source of food for humans can concentrate these viruses due to their filter feeding process [6]. These posses a public health threat as shellfish are often consumed raw or improperly cooked. A number of human enteric viruses including Norovirus, Aichi, Rotavirus, Enterovirus, adenovirus, astrovirus, Sapovirus, hepatitis A and hepatitis $\mathrm{E}$ virus have been detected in shellfish, but only a few reports have been linked to shellfish borne outbreaks $[7,8]$. Though surveillance studies indicate the presence of rotaviruses in bivalve

Copyright: The authors. This article is an open access article licensed under the terms of the Creative Commons Attributin License (http:// creative commons.org/licenses/by/2.0) which permits unrestricted use, distribution and reproduction in any medium, provided the work is properly cited. shellfish and aquatic water bodies [9-11] no shellfish borne outbreaks related to rota virus has been reported which may be due to absence of symptoms in adult population who are primary consumers of seafood rather than children.

The main objective of the study was to assess the prevalence of Rotavirus in shellfish from Kerala as previous reports has indicated the high incidence of Rotavirus in children from Kerala for which shellfish consumption may be a possible source.

\section{Materials and Methods}

\section{Ethical approval}

All the procedures have been carried out in accordance with the guidelines laid down by the Institutional Ethics Committee and in accordance with local laws and regulations.

\section{Samples}

A total of 200 shellfish samples were collected from October 2011 to February 2012. Samples were collected from various parts of Kollam and Trivandrum districts in Kerala. Three species of shellfish (brown mussel, yellow clamand black clam) were collected during the period (Table-1). Yellow clams were obtained from several retail markets in Kollam and were from Ashtamudi Lake. Black clams were collected directly from T S Canal in Kollam. Brown mussels were collected from various retail markets in Trivandrum. The samples were collected in sterile plastic bags, properly labelled and immediately transferred to the laboratory under chilled conditions and stored at $-20^{\circ} \mathrm{C}$ under further processing. 
Table-1: Shellfish samples.*

\begin{tabular}{llc}
\hline Species & Source & Numbers \\
\hline Brown mussels & Kovalam & 20 \\
& Vizhingam & 20 \\
\multirow{2}{*}{ Yellow clams } & Poovar & 20 \\
& Vaadi market & 40 \\
Black clams & Thevalli & 30 \\
& T S Canal & 70 \\
& Total & 200 \\
\hline
\end{tabular}

* Collected from various parts of Kollam and Trivandrum districts in Kerala

\section{Processing of samples}

The shellfish was washed in running tap water. The shells were shucked. The digestive diverticulum were cut into small pieces, homogenized with hand pestle and transferred to a $15 \mathrm{ml}$ centrifuge tube for concentration and extraction of virus RNA.

\section{Concenteration of virus}

A volume of $1 \mathrm{ml}$ of proteinase $\mathrm{K}(100 \mu \mathrm{g} / \mathrm{ml})$ (Fermentas) was added to the centrifuge tubes containing $1 \mathrm{~g}$ homogenized shellfish tissue. It was then kept in shaking the incubator at $180 \mathrm{rpm}$ at a temperature of $37^{\circ} \mathrm{C}$ for $1 \mathrm{~h}$. Proteinase $\mathrm{K}$ was inactivated by incubating in the water bath at $65^{\circ} \mathrm{C}$ for $15 \mathrm{~min}$. The supernatant was collected after centrifugation at $3000 \mathrm{rpm}$ for $5 \mathrm{~min}$ and stored at $-20^{\circ} \mathrm{C}$.

\section{Extraction of RNA from concentrated samples}

An aliquot of $1 \mathrm{ml}$ of supernatant was treated with 0.1 volumes of $10 \%$ of sodium dodecyl sulphate and incubated for $1 \mathrm{~h}$ at $56^{\circ} \mathrm{C}$ in the water bath. To this equal volume of phenol-choloroform-isoamyl alcohol mixture in a ratio of 25:24:1 was added. It was vortexed and centrifuged at $12,000 \mathrm{~g}$ for $15 \mathrm{~min}$. at $4^{\circ} \mathrm{C}$. The upper aqueous layer was carefully transferred to another tube without disturbing the interphase. It was mixed with equal volume of chloroform-isoamyl alcohol (24:1) and vortexed, then the mixture was centrifuged again at $12,000 \mathrm{~g}$ for $10 \mathrm{~min}$ and upper clear aqueous phase transferred to fresh microcentrifuge tube. To the aqueous phase 0.1 volume of $3 \mathrm{M}$ sodium acetate and equal volume of isopropanol were added and mixed gently. The samples were kept at $-20^{\circ} \mathrm{C}$ overnight for RNA precipitation. The RNA was pelleted by centrifugation at 10,000 g for $15 \mathrm{~min}$. The pellet obtained was washed with $1 \mathrm{ml}$ of $70 \%$ chilled ethanol to remove excess salts by centrifuging it at $10,000 \mathrm{~g}$ for $5 \mathrm{~min}$. The pellet was air dried and suspended in $20 \mu \mathrm{l}$ nuclease free water or RNA storing solution (Amresco), heated at $56^{\circ} \mathrm{C}$ for 5-10 min. to dissolve the pellet and stored at $-20^{\circ} \mathrm{C}$.

Reverse transcription-polymerase chain reaction ( RT-PCR) for detection of Rotavirus Preparation of $C D N A$

PCR tubes $(0.2 \mathrm{ml})$ were taken on ice and reaction mix was prepared as follows- $1 \mu$ l each of forward and reverse primer (rota 1 and rota 2 ) (Table-2), $1.5 \mu \mathrm{l}$ dimethyl sulfoxide, $5.5 \mu \mathrm{l}$ NFW and $5 \mu \mathrm{l}$ of
dsRNA for single reaction. The tubes were spun and boiled at $95^{\circ} \mathrm{C}$ for $5 \mathrm{~min}$ in a thermocycler (Eppendorf, Germany) and then snap chilled on ice. Following master mixture was separately prepared and dispensed in tubes containing RNA and primers. Master mixture was prepared by adding $2.5 \mu \mathrm{l}$ of $\times 5$ RT buffer, $2.0 \mu \mathrm{l}$ of $0.1 \mathrm{M}$ dithiothreitol, 0.4 mM dNTP, $0.5 \mu$ l RNAase inhibitor (40 U/ $\mu \mathrm{l}), 1 \mu \mathrm{l}$ of M-MuLV RT (20 U/ $\mu \mathrm{l})$ and $4 \mu \mathrm{l}$ NFW (Fermentas). After brief centrifugation, the tubes were loaded in thermolcycler under the following conditions of $37^{\circ} \mathrm{C}$ for $60 \mathrm{~min}$ and $65^{\circ} \mathrm{C}$ for $10 \mathrm{~min}$.

\section{PCR assay}

PCR mixture containing the following components was prepared- $2.5 \mu$ l of $\times 10$ PCR buffer without $\mathrm{MgCl}_{2}$ (Fermentas), $1.5 \mathrm{mM} \mathrm{MgCl}_{2}$ (Fermentas), $0.2 \mathrm{mM}$ dNTP (Fermentas), $1 \mu \mathrm{l}$ each of forward and reverse primers $(10 \mathrm{pmol} / \mu \mathrm{l})(\mathrm{GCC}), 0.2 \mu \mathrm{l}$ Taq DNA polymerase $(5 \mathrm{U} / \mu \mathrm{l})$ (Fermentas) and $13.3 \mu \mathrm{l} \mathrm{NFW}$ (Fermentas). To the PCR mixture $5 \mu$ l of cDNA was added. The tubes were briefly centrifuged and loaded on to thermal cycler, and the cycling conditions were set as follows. After an initial denaturation of $5 \mathrm{~min}$ at $94^{\circ} \mathrm{C}, 30$ cycles each of $1 \mathrm{~min}$ denaturation at $94^{\circ} \mathrm{C}$, annealing of $1 \mathrm{~min}$ at $55^{\circ} \mathrm{C}$ and $2 \mathrm{~min}$ extension at $72^{\circ} \mathrm{C}$ was carried out followed by a final extension for $7 \mathrm{~min}$ at $72^{\circ} \mathrm{C}$. The PCR products were stored at $-20^{\circ} \mathrm{C}$ until further use. PCR product was visualized using agarose gel electrophoresis.

\section{Results}

Of the total 200 shellfish samples screened by RT-PCR for the presence of Rotavirus five samples were positive with an overall prevalence of $2.5 \%$. (Figure-1) Rotavirus was detected in 2 out of 60 brown mussels (3.33\%), 2 out of 70 yellow clams (2.86\%) and 1 out of 70 black clams (1.43\%). Rotavirus could be detected only in brown mussel collected from Vizhingam, yellow clam from Vaadi market and black clam from T S Canal as depicted in the Table-3.

\section{Discussion}

Rotaviruses are the main etiological agent of viral gastroenteritis in infants and young children. Many viruses transmitted by the faecal-oral route are widely prevalent in the community, and infected individuals can shed millions of virus particles in their faeces. Concentrations of $3 \times 10^{5}-5 \times 10^{11}$ viral particles/g of stool have been reported for Rotavirus [13] while the infective dose is as low as 10-100 virus particles [14]. Shedding of large quantities of virus in stool begins 2 days before the onset of diarrhoea and last for up to 10 days after onset of symptoms. Enteric virus including Rotavirus can thus contaminate shellfish growing areas from a number of sources including septic tank leakages, boat discharges, overflows and spills from sewage treatment plants seepage from sewage reticulation networks and accidental contamination after heavy rainfall. 
Table-2: Primers used in the study.

\begin{tabular}{llllcr}
\hline Virus & Gene & Primer name & Primer sequence & Product size & Reference \\
\hline Rota & Vp7 & Rota 1 & 5'GATCCGAATGGTTGTGTAATCCAAT3' & 304 bp & [12] \\
virus & & Rota 2 & 5'AATTCGCTACGTTTCTCTTGG3' & & \\
\hline
\end{tabular}

Table-3: Prevalence of Rotavirus in shellfish by RT-PCR.

\begin{tabular}{llcc}
\hline Species & Source & $\begin{array}{c}\text { Number of } \\
\text { screened }\end{array}$ & $\begin{array}{c}\text { Number } \\
\text { of positive }\end{array}$ \\
\hline Brown mussel & Kovalam & 20 & Nil \\
& Vizhingam & 20 & 2 \\
\multirow{4}{*}{ Yellow clams } & Poovar & 20 & Nil \\
& Vaadi market & 40 & 2 \\
Black clam & Thevalli & 30 & Nil \\
& T S Canal & 70 & 1 \\
& & 200 & 5 \\
\hline
\end{tabular}

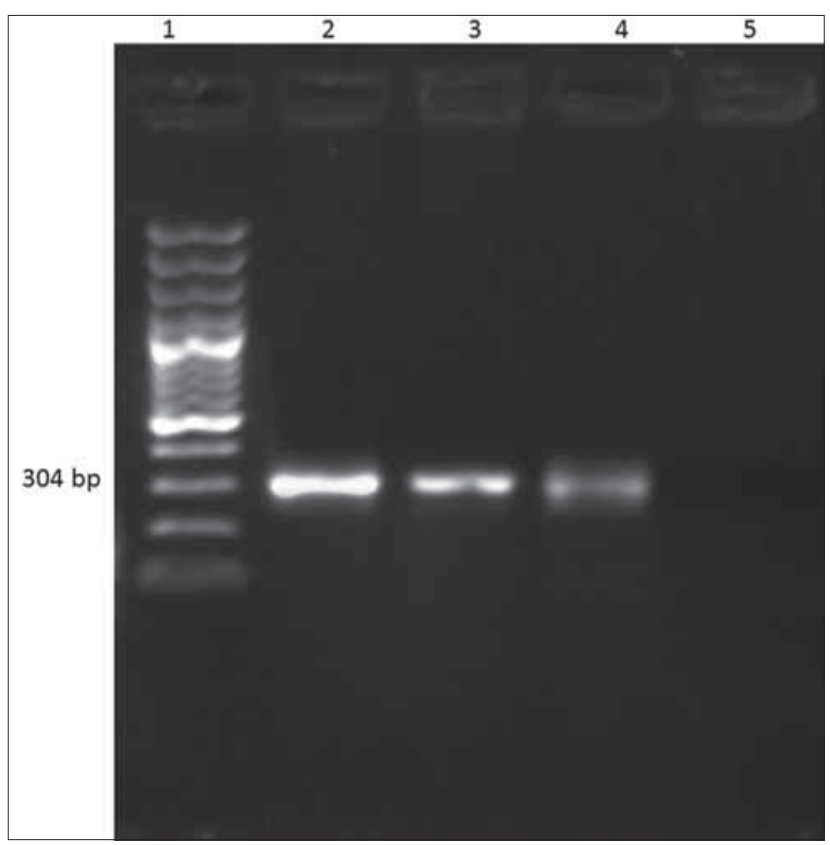

Figure-1: Shellfish samples positive for rotavirus. Lane 1: 100 bp ladder. Lane 2: Positive control. Lane 3-4: Positive shellfish samples. Lane 5: Negative control.

Enteric viruses in contrast to enteric bacteria persist in shellfish for an extended period which will have a significant impact on public health. Viruses are mainly concentrated in the pancreatic tissue, also called digestive diverticula. Virus accumulation in shellfish occurs by different mechanisms including mechanical entrapment and ionic bonding [6]. Virus accumulation in shellfish depends on factors such as water temperature, mucus production, glycogen content of the connective tissue, and gonadal development [15].

The low prevalence of Rotavirus was observed in the present study. The low prevalence observed in our study may be due to presence of PCR inhibitors that are normally present in shellfish or may be due to low concentration of Rotavirus present in shellfish. Although no reports are available in India regarding the prevalence of Rotavirus in shellfish, a high prevalence of Rotavirus in children from Kerala has been reported [16]. Similar results were obtained in a study in China where in $3.33 \%$ of the shellfish samples were positive for Rotavirus [17]. Rotavirus has been reported in shellfish from other parts of the world. Prevalence as high as 52\% have been reported in a 3 year-long study in southern France [18] and as low as $0.5 \%$ in Puglia in Italy [19] have been reported.

\section{Conclusion}

A low prevalence of $2.5 \%$ of rotaviral RNA could be detected in our study. Only limited studies have been done in India in this area and more extensive studies have to be undertaken to understand the true prevalence of enteric virus in shellfish in India. Shellfish consumption may thus be regarded as a twofaced issue, on the one hand as a delicious food providing nutrient, and on the other, a matter of concern as shellfish is a common cause for infections such as gastroenteritis or hepatitis.

\section{Authors' Contributions}

This study was a part of VM's M.V.Sc. thesis under the guidance of KNB. KNB designed the experiment, sample collection was done by VM and DAR. Experiment was performed by VM and assisted by SR, KML, HVM under guidance of KNB. Manuscript preparation was supervised, reviewed and edited by KNB and AK. All authors read and approved the final manuscript.

\section{Acknowledgments}

The authors are thankful to the Director, Indian Veterinary Research Institute, Izatnagar for providing necessary facilities to carry out this work. This research was funded by Indian Council of Agricultural Research (ICAR), India.

\section{Competing I nterests}

The authors declare that they have no competing interests.

\section{References}

1. Black, R.E., Cousens, S., Johnson, H.L., Lawn, J.E., Rudan, I., Bassani, D.G., Jha, P., Campbell, H., Walker, C.F., Cibulskis, R., Eisele, T., Liu, L. and Mathers, C. (2010) Global, regional, and national causes of child mortality in 2008: A systematic analysis. Lancet., 375(9730): 1969-1987.

2. Million Death Study Collaborators. (2010) Causes of neonatal and child mortality in India: nationally representative mortality survey. Lancet., 376(9755): 1853.

3. Parashar, U.D., Burton, A., Lanata, C., Boschi-Pinto, C., Shibuya, K., Steele, D., Birmingham, M. and Glass, R.I. (2009) Global mortality associated with Rotavirus disease among children in 2004. J. Infect. Dis., 200 Suppl 1: S9-S15. 
4. Tate, J.E., Chitambar, S., Esposito, D.H., Sarkar, R., Gladstone,B., Ramani, S., Raghava,M.V.,Sowmyanarayanan, T.V., Gandhe, S., Arora, R., Parashar, U.D. and Kang G. (2009) Disease and economic burden of Rotavirus diarrhoea in India. Vaccine, 27: F18-F24.

5. Leclerc, H., Edberg, S., Pierzo, V. and Delattre, J.M. (2000) Bacteriophages as indicators of enteric viruses and public health risk in ground waters. J. Appl. Microbiol., 88(1): 5-21.

6. Burkhardt, W. and Calci, K.R. (2000) Selective accumulation may account for shellfish-associated viral illness. Appl. Environ. Microbiol., 66(4): 1375-1378.

7. Le Guyader, F., Haugarreau, L., Miossec, L., Dubois, E. and Pommepuy, M. (2000) Three-year study to assess human enteric viruses in shellfish. Appl. Environ. Microbiol., 66(8): 3241-3248.

8. Nakagawa-Okamoto, R., Arita-Nishida, T., Toda, S., Kato, H., Iwata, H., Akiyama, M., Nishio, O., Kimura, H., Noda, M., Takeda, N. and Oka, T. (2009) Detection of multiple sapovirus genotypes and genogroups in oyster-associated outbreaks. Jpn. J. Infect. Dis., 62(1): 63-66.

9. Sdiri-Loulizi, K., Hassine, M., Aouni, Z., Gharbi-Khelifi, H., Chouchane, S., Sakly, N., Neji-Guédiche, M., Pothier, P., Aouni, M. and Ambert-Balay, K. (2010) Detection and molecular characterization of enteric viruses in environmental samples in Monastir, Tunisia between January 2003 and April 2007. J. Appl. Microbiol., 109: 1093-1104.

10. Rigotto, C., Victoria, M., Moresco, V., Kolesnikovas, C.K., Corrêa, A.A., Souza, D.S., Miagostovich, M.P., Simões, C.M. and Barardi, C.R. (2010) Assessment of adenovirus, hepatitis A virus and rotavirus presence in environmental samples in Florianopolis, South Brazil. J. Appl. Microbiol., 109(6): 1979-1987.
11. Keller, R., Justino, J.F. and Cassini, S.T. (2013) Assessment of water and seafood microbiology quality in a mangrove region in Vitória, Brazil. J. Water Health., 11(3): 573-580.

12. Hussain, M., Seth, P. and Broor, S. (1995) Detection of group A Rotavirus by reverse transcriptase and polymerase chain reaction in faeces from children with acute gastroenteritis. Arch. Virol., 140(7): 1225-1233.

13. Bishop, R.F. (1996) Natural history of human Rotavirus infection. Arch. Virol. Suppl., 12: 119-128.

14. Graham, D.Y., Dufour, G.R. and Estes, M.K. (1987) Minimal infective dose of Rotavirus. Arch. Virol., 92(3-4): 261-271.

15. Di Girolamo, R., Liston, J. and Matches, J. (1977) Ionic binding, the mechanism of viral uptake by shellfish mucus. Appl. Environ. Microbiol., 33(1): 19-25.

16. Mathew, M.A., Paulose, A., Chitralekha, S., Nair, M.K.C., Kang, G. and Kilgore, P. (2014 Prevalence of rotavirus diarrhea among hospitalized under-five children. Indian Pediatr., 51(1): 27-31.

17. Kou, X.X., Wu, Q.P., Zang, J.M. and Fan, H.Y. (2005) Study on rotavirus detection with single-tube seminested RT-PCR method in shellfish. Wei Sheng Wu Xue Bao., 45(3): 401-404.

18. Le Guyader, F.S., Haugarreau, L., Miossec, L., Dubois, E. and Pommepuy, M. (2001) Three-Year study to assess human enteric viruses in shellfish. Appl. Environ. Microbiol., 67: 490.

19. Chironna, M., Germinario, C., De Medici, D., Fiore, A., Di Pasquale, S., Quarto, M. and Barbuti, S. (2002) Detection of hepatitis a in mussels from different sources marketed in Puglia region (South Italy). Int. J. Food Microbiol., 75(1-2): 11-18. 